\title{
VCT Counselor Activities in handling HIV Patients in RSUD Karawang District Case Study of VCT Counseling Activities in HIV Patient Management at RSUD Karawang
}

\author{
Siti Nursanti \\ Universitas Singaperbangsa Karawang \\ Indonesia \\ siti.nursanti@staff.unsika.ac.id
}

\begin{abstract}
VCT counseling is one of the hospital services that specialize in self-care to serve HIV / AIDS-indicated patients. VCT counseling can only be done by a certified specialist. This study aims to examine how the communication process that occurs in the practice of VCT Counseling services conducted by health personnel and why VCT counseling activities should be done by health petugs in RSUD Karawang. This study uses a case study approach considering the uniqueness of the VCT Counseling process that can only be done by certified health workers. The results of this study are effective communication process required in the organization of VCT activities in the hospital, effective communication skills, assistance from peer support groups and government policies in the provision of material support for VCT counseling officers is expected to be one of the effective activities to prevent the spread of HIV AIDS virus.
\end{abstract}

Keywords-VCT counseling; counselor effective communication; effective health communication

\section{INTRODUCTION}

Poly Alternative is a poly clinic that performs services to HIV patients, a unique name given to the poly to hide the practice of services that occur within the poly, explained Mr. Ade Ruhyana one of VCT (Voluntary Counseling and Testing) officers RSUD Karawang West Java. VCT is a voluntary HIV-testing program conducted by HIV-induced patients, VCT can only be done in hospitals that have been appointed by the government to open HIV testing services and have a certified health worker to accompany patients and prepare patients for examination and admission result of the examination.

The spread of HIV in Karawang regency is quite apprehensive, most patients who come in RSUD Karawang are patients who come from the sub-district which is quite far from the heart of karawang city, the awareness of patients to conduct examination and treatment for those who have been infected with the HIV virus began to rise so that patients do more voluntary test every month so explanation of Mr. Yoyo Kuswoyo one of VCT officer in RSUD Karawang. Awareness of the patient to test HIV because the more easily the public gets information about HIV virus, prevention and treatment.
Acquired Immune Deficiency Syndrome (AIDS) has indeed become a very serious epidemic threatening the health of the world community. International figures show more than 14,000 new infections occur daily and an estimated 40.3 million people living with HIV / AIDS status in the world in 2005. According to World Health Organization (WHO) people with HIV / AIDS potentially infect about 200 other people. (Kompas, 2008) In 1987, there were only nine HIV / AIDS cases in Indonesia whereas based on data from the Ministry of Health of the Republic of Indonesia until June 2008, there were 18,936 HIV / AIDS cases in Indonesia, which means within 21 years, HIV / AIDS increased 2,000\%. Central Java Provincial Health Office data shows, cumulatively until March 2005 the number of HIV / AIDS sufferers in Central Java has reached 407 people and not less than 11 percent of them are AIDS sufferers.. Most $71.43 \%$ were sexually transmitted and about $25.71 \%$ spread among injecting drug users, while the rest were transmitted from HIV / AIDS mothers to their babies [1].

VCT activities are expected to be one way to break the link of HIV AIDS spread, explains Mr. Ade Ruhyana. VCT activities can only be conducted in government hospitals and run by officers who have undergone special training. Interviews with three informants found that in order to improve the quality of care, the quality of the counselor should also support, among others, specific training for HIV counselors: in this counselor training conducted by international organizations, there is a special training in Jakarta for 3 full days, the training is organized by WHO. Counseling should be performed by trained counselors who have counseling skills and understanding of the ins and outs of HIV / AIDS [1].

There is no specific criterion or special incentive to become a VCT counselor, just a medical or paramedic person who has a warrant from the hospital and of course has a training certificate issued by the relevant institution. However, communication skills are needed specifically to survive as a counselor, explains Yoyo Kuswoyo. It's all back to the awareness of individuals to care about the patients with HIV AIDS, can imagine what kind of world will be enjoyed by our 
grandchildren kits if we do not care. In principle, officers who perform VCT should not always be a doctor but can also be done by nurses, midwives, other health workers or important social workers have followed VCT training [2].

VCT counseling activities conducted by health workers in hospitals Karawang be uniquely to be researched by researchers by using a case study approach. As a case study, the data collected comes from various sources and the results of this study apply only to the cases investigated. Further, Arikunto [3] suggests that the case study method as one of the descriptive approaches, is an intensive, detailed and in-depth study of a particular organism (individual), institution or symptom with a narrow area or subject. This study aims to discover the uniqueness of how the communication process that occurs in VCT counseling in RSUD Karawang and why the process of effective communication needs to be done in VCT activities in RSUD Karawang.

\section{RESEARCH METHODS}

The research paradigm in this study, using naturalistic paradigms within the scope of the sociocultural tradition, researchers naturally examine the existence of social and cultural research subjects, where communication is focused on social reality. Researchers in seeing the phenomenon of VCT counseling process conducted by VCT counselor in RSUD Karawang try to think carefully, looking for the framework in accordance with naturalistic science communication studies. Researchers are in a neutral position, and look for a complete picture of the communication process. This paradigm is a collection of shared logical assumptions, concepts, or propositions that guide thinking and research. Theoretical orientation or perspective is the way to see the world, what people think is important, and what makes the world work. The paradigm is a framework that contains the concept and map (whole) of the study [4].

In this study, researchers used qualitative methods with Case Study approach. Researchers consider this method is very appropriate to be a way that can describe the phenomenon in research VCT Counseling Process conducted by VCT officers in RSUD Karawang. As described by [5] thick description, about the complex process and its effects. In certain contexts. The ability to provide rich portraits in this way is a key benefit of case studies. Your research reader should be made to feel as if you were there with you in your research, see what you see, summarize what you have concluded [6, p. 174].

According to Patton, the process of preparation of case studies takes place in three stages. The first stage is the collection of raw data about individuals, organizations, programs, places of incidence on which case studies are written. The second step is to compile or manage cases that have been obtained through compacting, summarizing data that is still in raw data form, classifying and editing and putting it into one manageable, (manageable) and easily accessible file. The third step is to write a final case report of a narrative [7, p. 51]. In qualitative research, researchers naturally see problems in the context of research, researchers plunge into the events and conditions that occur in the context of research. Researchers are directly in the field on various sides of events that occur during the observation process takes place. In this study, which will be the source source is 2 VCT officers, Head of RSUD Karawang and a peer support group officer involved in VCT counseling activities.

\section{DISCUSSION}

Karawang regency is located in the northern part of West Java Province with an area of $1.753,27 \mathrm{~km} 2$ or 175,327 ha. This area constitutes $3.73 \%$ of West Java Province, Geographically located between $107.02^{\circ}$ East $-107.40^{\circ}$ East and $5.56^{\circ}$ South $-6.34^{\circ}$ South, including relatively low altitude, having a variation in altitude between $0-1,279$ meters in above sea level with a slope of $0-2^{\circ}, 2-15^{\circ}, 15$ $40^{\circ}$, and above $40^{\circ}$ with an average temperature of $27^{\circ} \mathrm{C}$.

Administratively Karawang regency has boundaries as follows:

- $\quad$ North with Java Sea;

- $\quad$ East with Subang Regency;

- Southeast with Purwakarta Regency;

- South with Kabupaten Bogor and Kabupaten Cianjur;

- West with Bekasi Regency

The existence of RSUD Karawang regency in West Java is as referral hospital of Karawang regency and surrounding area (Purwasuka) and supporting health service of industrial employee, in line with increasing of public demand toward health service in hospital. RSUD Karawang started to open alternative poly service in 2010, initially alternative poly was used to serve patient of HIV AIDS and Patient of psychiatric disorders, along with increasing number of HIV AIDS patient visit hence since 2017 alternative poly specialize self to serve HIV AIDS patient. Limitations of labor became one of the obstacles in the VCT Counseling Process service in RSUD Karawang, the average visitation rate of 20 patients in one day served by 3 VCT officers. Each VCT counseling officer must have time management in order that the process of getting to know each other or approach with the patient can be done well.

AIDS Commission (KPA) Karawang regency, West Java, recorded as many as 17 people with HIV AIDS (PLWHA) died throughout 2017. KPA staff Karawang, Awan Gunawan, said the total number of HIV / AIDS cases in Karawang has reached 807 cases from 2001 -2017. While throughout 2017 there are 136 cases of HIV / AIDS who died. Every month patients who come with their own awareness and invitations from KDS staff (Peer Support Groups) are increasing, indicating that public awareness of HIV AIDS is on the rise, explained Ade Ruhyana, one of the VCT Counseling Officers at RSUD Karawang.

Ade Ruhyana explains at least needed some criteria as follows to become VCT Counseling officer that is (1) have attended special certified training for VCT counseling organizers conducted by the Ministry of Health, (2) appointed by the Decree of Director of Hospital, (3) have the ability to communicate effectively, and (4), have concern for patients. 
Effective communication becomes the key word in VCT counseling activity, we are momentarily become a health worker but on other occasions we have to be a friend who will help them become better human being and able to be friend talk and friend to discuss through all the problems that will be faced throughout life by HIV AIDS patients, explains Yoyo Kuswoyo, one of the VCT counseling officers. Transactional Communication model that puts the patient is not just an object, but as a subject with a socio-cultural background, values, hopes, feelings, desires, worries, and also crave happiness.

Being in Alternative Polyies is like being in your own environment, we seem to have a hope for life to be better. We try to solve the problem together to support each other and encourage each other. The world feels like it will collapse the first time in opening the results and then tested positive for the HIV AIDS virus explains Rian as one of the KDS activists. We cannot just keep silent, support VCT counseling officers become one of the spark in this life.

VCT counseling personnel are provided with information tools to help explain and prepare patients for the VCT counseling process, such as leaflets, brochures, props and clue cards that can be used to provide information about HIV AIDS. Media information is obtained from the KPA, Ministry of health and some are made by VCT counseling officers as well, this information media can actually take home by the patient only most patients are reluctant to bring the media information is due to fear of the assumption of people who do not understand with what which he is experiencing right now.

Conceptually VCT counseling officers are tasked with motivating patients to break the chain of HIV disease in the community, ensuring that the patient recognizes the condition of the body and what to do so that the patient can improve his or her own health. The motivation of VCT Counseling officers to continue their work as VCT counseling is a sense of responsibility in doing their work and preventing the spread of HIV AIDS in the community. The phenomenon of HIV AIDS viruses such as icebergs that are not visible but store various kinds of problems in the future will endanger our children and grandchildren so explanation of VCT counseling officers in RSUD Karawang.

The Peer Support Group is one of the partners for VCT counseling, Peer Support Group is not a non-governmental organization but a foundation that specializes in helping patients live a better life. VCT Counseling Officers need partners to ensure HIV AIDS patients live a healthy lifestyle and are willing to take regular medication and come to consult at least once a month. It is not easy to practice profession as VCT counseling officer since the government has not allocated special fund for VCT counseling officer.

The process of VCT counseling is different from serving the usual patients who come to the hospital, the relationship of health workers with HIV AIDS patients does not just stop at the counseling room at the hospital, sometimes the patient needs the worker to work. VCT Counseling Officers must be ready for 1 x 24 hours to receive consultations through mobile phones, sometimes into relationships like relatives. This we live solely to meet the demands of the job thus explains Ade ruhyana one of the VCT counseling officers. In addition a VCT Counseling should be able to maintain patient confidentiality and ensure patients are not threatened by the presence of health workers.

VCT is essential to accessing all necessary services related to prevention and treatment of HIV, AIDS, as well as providing support for clients' needs such as behavioral change, mental support, ARV therapy support, and correct and factual understanding of HIV, AIDS. VCT can be obtained at a health care facility or clinic that provides VCT, Puskesmas, and RS services. It literally means Voluntary Tests and Counseling. But this is a voluntary and confidential counseling activity, conducted by a trained VCT counselor, conducted before and after the blood test for HIV in the laboratory. An HIV test is performed after the client first signs an informed consent. Constraints that occur in hospitals Karawang one of them is a room that is used to make explanations to patients associated with the place, classroom class III to class I during this patient not only alone in the room so it is possible when the officer gives an explanation about his condition did not close the possibility of patients others in the room heard what was being said. Patient confidentiality becomes one of the key beliefs of patients to health care workers, the patient's psychological condition becomes one of the determinants of the success of VCT counseling.

This VCT is needed by everyone who wants to do HIV testing and for people who have had an act or behavior at risk of contracting HIV such as sexual activity, tattoo piercing, drug consumption through needles and other salts and want to do something for the future. For a VCT counselor it is important to have interpersonal communication skills such as listening ability, speaking ability and empathy ability towards clients or patients. Given the stigma in the community about the HIV virus, it is imperative that a counselor chooses a language and approaches the client according to the background of the client. Effective communication can occur when communicants and communicators are warm from the same point, there are conditions where the patient feels that the condition is fine and does not require further examination, and the essence of communication is perception. Equating perceptions between patients, VCT counselors and community stigma are key to the success of VCT activities.

For that VCT service becomes very important. The more people whose behaviors are at higher risk of getting HIV testing for HIV will get better. At least, there are two important advantages when we know our HIV status. First, when infected with HIV, we can take the necessary steps that potentially prolong life. Second, we can take all the vigilance that is deemed necessary to prevent the spread of HIV to others.

In Indonesia HIV counselors gather in a forum called VCT HIV Counselors Association of Indonesia (PKVHI), a professional organization composed of HIV-AIDS counselors with diverse educational backgrounds, trained VCT with national and professional standards in the development of VCT services in Indonesia. PKVHI was established on April 
29, 2008, headquartered in Jakarta and has territory in all provinces to districts / cities.

\section{CONCLUSION}

In this study it was concluded that the effective communication process is needed in the organization of VCT activities in the hospital, effective communication skills, assistance from peer support group and government policy in providing material support for VCT counseling officers is expected to be one of the effective activities to prevent the spread of HIV virus AIDS. The concern of all parties will be a force to prevent the spread of HIV AIDS virus, VCT counseling program will not be done well if less support from all parties. Tackling the spread of the HIV AIDS virus is not just the obligation of VCT counseling officers but our obligations are all. Stigma in society is one of the biggest communication inhibiting factors in VCT counseling, people still think those who are exposed to the HIV AIDS virus are the people's waste that should be shunned as a factor making their aversion exposed to the HIV virus to come and receive further treatment.

\section{REFERENCES}

[1] D. Dayaningsih, "Studi Fenomologi Pelaksanaan HIV Voluntary Counseling And Testing (VCT) DI RSUP dr. Kariadi Semarang [Phenomenological Studies of the Implementation of HIV Voluntary Counseling and Testing (VCT) in dr. Kariadi Central General Hospital, Semarang]," Jurn. Keperawat., vol. 18, no. 1, pp. 4-5, 2009.

[2] Y. Maani and N. Balqis, "Gambaran Implementasi Program Pelayanan Voluntary Counselling and Testing (VCT) di Puskesmas Jongaya Makasar Tahun 2013 [Description of the Implementation of the Service Program of Voluntary Counselling and Testing (VCT) in Jongaya Public Health Center, Makassar in 2013]." UNHAS Makasar, 2013.

[3] A. S. Hamdi and E. Bahruddin E. Metode penelitian kuantitatif aplikasi dalam pendidikan [Quantitative research method, application in education]. Deepublish, 2015.

[4] S. Endraswara, Metode pengajaran apresiasi sastra [Teaching method of literature appreciation]. Yogyakarta: Radhita Buana, 2002.

[5] C. Geertz, "Thick description: Toward an interpretive theory of culture," Read. in the philos. of soc. sci., pp. 213-231, 1994.

[6] L. Brown, "The transformative power of the international sojourn: An ethnographic study of the international student experience," Ann. of touri. res., vol. 36, no. 3, pp. 502-521, 2009.

[7] J. Raco, Metode Peneltian Kualitatif [Qualitative Research Method]. Grasindo, 2010. 